\title{
Prevalence of postural deviations in the spine in schoolchildren: a systematic review with meta-analysis
}

\author{
Ana Paula Kasten ${ }^{1}$, Bruna Nichele da Rosa ${ }^{1}$, Emanuelle Francine Detogni Schmit ${ }^{1}$, Matias Noll' ${ }^{1}$, Cláudia Tarragô Candotti ${ }^{1}$
}

\begin{abstract}
Introduction: The Information Age has had a major impact on citizens' lives. The invention of machinery, automobile, television and computer have induced individuals to adopt the "sitting" body posture in order to adapt to new technological needs.
\end{abstract}

Objective: To estimate the prevalence of spine postural deviations in Brazilian schoolchildren.

Methods: Searches were conducted in databases EMBASE, LILACS, PubMed, SCOPUS, SciELO, Science Direct, and Web of Science, as well as manual searches to identify studies that evaluated the prevalence of spine postural deviations in Brazilian schoolchildren. Two independent reviewers realized the study selection, evaluated the methodological quality and the risk of bias and extracted data. The homogeneity between the studies was evaluated and the quality of evidence level using the GRADE system.

Results: 29 studies were included, of which extracted the frequency of positive events to changes in cervical, thoracic and lumbar spine, as well as the frequency of scoliosis between schoolchildren. Even performing the meta-analysis separated by subgroups according to the spine region, the heterogeneity level it was up to $90 \%$, it is not possible to perform the meta-analysis to estimate the prevalence of spine postural deviations in Brazilian schoolchildren.

Conclusion: There is low strength of evidence to establish a consensus about the values of the prevalence of spine postural deviations in Brazilian schoolchildren.

Keywords: posture, spine, child, adolescent.

\section{INTRODUCTION}

The Information Age has had a major impact on citizens' lives ${ }^{1}$. The invention of machinery, automobile, television and computer have induced individuals to adopt the "sitting" body posture in order to adapt to new technological needs. Also, the increasing rate of adhesion of individuals to the new demands of convenience comfort has been an important causal factor of poor posture and back pain. Thus, both inadequate and sedentary habits, since childhood, contribute to the appearance of muscle weakness and ligament laxity, overloading the spine, which results in suffering, pain and disability ${ }^{2-5}$.

In addition, it has been accepted that postural problems related to changes in body shape often have their origin in childhood, especially those related to the spine ${ }^{6}$. In this sense, the identification or diagnosis of postural de- viations during childhood and adolescence is of great importance in this phase of body growth and development, since the correction of these changes is mainly based on global posture reeducation. In fact, investing in reeducation during childhood and adolescence tends to minimize the need for a future conservative treatment that only aims to improve symptoms, since, after adolescence, bone growth has already ceased ${ }^{7,8}$.

Some factors are preponderant in the causes of postural deviations in school-age children, such as, hours sitting in inappropriate positions in the classroom, inadequate seats, carrying school supplies in an inadequate way $^{9-11}$ and / or with weight above $10 \%$ of body weight ${ }^{5-10}$. In addition, the increase in Body Mass Index (BMI) in students diagnosed as pre-obese and obese results in a higher prevalence of asymmetry in the anterior, posterior and lateral planes ${ }^{12-14}$. In fact, these factors are evident world-

\footnotetext{
1 Federal University of Rio Grande do Sul.

Corresponding author: Ana Paula Kasten - E-mail: anapaulakasten@hotmail.com
}

Suggested citation: Kasten AP, Rosa BN, Schmit EFD, Noll M, Candotti CT. Prevalence of postural changes in the spine in schoolchildren: a systematic review with meta-analysis. J Hum Growth Dev. 2017; 27(1): 99-108. Doi: http://dx.doi.org/10.7322/jhgd.127684

Manuscript submitted 2016, accepted for publication Jun 2016. 
wide, in both developed and developing countries. In Iran, a developing country, two studies found a higher prevalence of changes in the spine of girls associated with sedentary lifestyle and excess weight carried in backpacks during the carrying of school supplies ${ }^{15,16}$. In Japan, a developed country, a longitudinal study found an inverse relationship between paravertebral muscle strength and lumbosacral postural change. That is, during a 10-year follow-up, there was both a decrease in paravertebral muscle strength and an increase of around $10^{\circ}$ in the lumbosacral angle, suggesting the need to promote activities to maintain muscle strength from childhood and adolescence ${ }^{17,18}$.

Regarding developing countries, although Brazil stands out for the amount of research on the subject of school posture, as far as we know, no study was conducted synthesizing the Brazilian reality about the prevalence of postural deviations, especially those related to the spine. Thus, considering that knowledge of the profile of postural deviations in schoolchildren and adolescents is essential to assist in the development of public policies and intervention strategies, the objective of this study is to estimate the prevalence of postural deviations in Brazilian schoolchildren's spine through a systematic review with meta-analysis.

\section{METHODS}

\section{Type of study}

This study comprised a systematic review of the literature $^{19}$, registered in PROSPERO under the code CRD42015026504, and guided according to the recommendations of the Joanna Briggs Institute Reviewers Manual (The Systematic Reviewer of Prevalence and Incidence Data) $)^{20}$, the guidelines of Collaboration Cochrane ${ }^{21}$ and the MOOSE (MetaAnalysis of Observational Studies in Epidemiology) report ${ }^{22}$.

\section{Search strategy}

In order to achieve the proposed objective, we conducted searches from September 23 to 25, 2015, in the EMBASE, LILACS, PubMed, SCOPUS, SciELO, Science Direct, and Web of Science databases. The terms and Boolean operators used were: "students" [AND] "spinal curvatures" [AND] "prevalence". No restriction of language and year of publication was done in the search, which was performed from the beginning of the bases until the moment of the search. The studies should be of the observational type. Manual searches were also conducted in the references of included studies. Table 1 presents the search strategy used in the PubMed database, and in the other databases this strategy was adapted according to the guidelines of each database.

\section{Table 1: Search strategy - PubMed}

\#1 ("Students"[Mesh] OR "Students" OR "schoolchildren")

\#2 ("Spinal Curvatures"[Mesh] OR "Spinal Curvatures” OR "Hyperkyphosis”[Mesh] OR "Hyperkyphosis” OR "Lordosis"[Mesh] OR "Lordosis" OR "Scoliosis"[Mesh] OR "Scoliosis")

\#3 ("Prevalence"[Mesh] OR "Prevalence")

\#4 (\#1 AND \#2 AND \#3)

\section{Eligibility Criteria}

Two independent evaluatorsselected the potentially relevant studies from the titles, abstracts and full text. The studies selected for reading in full were evaluated according to the following eligibility criteria: (a) observational study; (B) exclusive sample of Brazilian schoolchildren aged 6 to 18 years; (C) to address the prevalence of postural deviations in the spine. Discordant cases were resolved by consensus ${ }^{23}$.

\section{Assessment of Studies}

The evaluators obtained the study data independently and in a standardized form according to the following information: authors, year of publication, place of the holding of the study, sample evaluated, methods used and prevalence of changes in the spine.

Likewise, the studies were evaluated with respect to methodological quality and risk of bias through the Prevalence Critical Appraisal Instrument ${ }^{24}$, an instrument developed to evaluate the methodological quality of studies that present prevalence data. This instrument consists of 10 items, which must be filled in as Yes, No, Unclear or Not Applicable, and then the items filled with Yes are punctuated. In this perspective, the evaluation of each study can present a score between 0 and 10 , and the higher the score, the better the methodological evaluation of the study. In order to graduate and establish categorical divisions of quality, a cutoff point was stipulated, with the minimum score of seven as the divisor between studies of high quality (score of 7 to 10) and low or moderate (score from 0 to 6 ). This cut-off point was chosen arbitrarily, since there are no stipulated classifications for this tool ${ }^{20}$. In order to measure the agreement between the reviewers in assigning the scores for each study, an Intraclass Correlation Coefficient was performed via SPSS v. 20.0 software, which was classified as: poor $(\mathrm{ICC}<0.4)$, satisfactory $(0.4 \leq \mathrm{ICC}<0.75)$ and excellent $(\mathrm{ICC} \geq 0.75)^{25}$.

\section{Statistical Analysis}

The data was initially analyzed by means of descriptive statistics, separated into subgroups according to the vertebral region associated with the changes and the instrument of analysis. A meta-analysis was performed using the Comprehensive Meta-Analysis, version 2.2.04 (Biostat, Inc. (C), Englewood, New Jersey) and Med$\mathrm{Calc}^{26}$, version 11.0 (MedCalc Software, Mariakerke, Belgium) software by means of inferential statistics with the Higgins Inconsistency Test $\left(\mathrm{I}^{2}\right)^{21}$ to verify homogeneity of the subjects. The heterogeneity was considered low if $\mathrm{I}^{2}<50 \%$ and moderate / high if $\mathrm{I}^{2} \geq 50 \%$. In cases of $\mathrm{I}^{2} \geq 50 \%$, we opted for the adoption of the random models effect. The sensitivity analysis encompassed the exclusion of studies based on a sample calculation performed 
for each subgroup, using the recommendations of Santos, Abbud and $\mathrm{Abreu}^{27}$, that is, for each subgroup, sample calculations were performed from three different values of prevalence - low, intermediate and high (Table 2). Thus, the studies included in the systematic review that had not recruited the minimum sample to meet the proposed objective were excluded from the meta-analysis. However, even with the sensitivity analysis based on the inclusion of studies with a minimum sample size corresponding to the one obtained by the sample calculation, it was not possible to reduce or minimize the heterogeneity present in the studies. Therefore, the presentations of the meta-analysis in subgroups according to the vertebral region associated with the changes were maintained in general, in order to highlight the methodological differences between the studies. (Supplementary material)

\section{Strength of evidence}

In order to summarize the general quality of the evidence, the GRADE (Grading of Recommendations Assessment, Development, and Evaluation) system was used $^{28}$. GRADE classifies the quality of evidence and the strength of recommendation provided by systematic reviews, scientific advice, and clinical guidelines. It is a way of representing confidence in the information provided, by classifying the level of evidence and by expressing the emphasis so that a particular conduct is adopted or rejected in the case of reviews of clinical trials ${ }^{29}$. We analyzed only observational studies, and only the classification of their level of evidence was used. The quality of evidence evaluation was based on the following criteria: design of studies included in the systematic review; methodological limitations of included studies;

Table 2: Studies used for sample calculation of each subgroup of analysis (cervical, thoracic, lumbar and scoliosis).

\begin{tabular}{lcccc}
\hline $\begin{array}{l}\text { Analysis } \\
\text { Subgroup }\end{array}$ & Article & Sample Size (n) & Prevalence (\%) & $\begin{array}{c}\text { Minimum sample } \\
\text { size obtained by } \\
\text { by calculation (n) }\end{array}$ \\
\hline \multirow{3}{*}{ Cervical } & Santos et al. (2009) & 247 & 11.7 & 162 \\
& Lemos, Santos and Gaya (2012) & 467 & 36.4 & 354 \\
Thoracic & Detsch and Candotti (2001) & 154 & 66.2 & 345 \\
& Santos et al. (2009) & 247 & 9.7 & 369 \\
Lumbar & Bastião et al. (2014) & 420 & 40.5 & 345 \\
& Noll et al. (2012) & 65 & 66.1 & 296 \\
Scoliosis & Santos et al. (2009) & 247 & 26.3 & 329 \\
& Detsch and Candotti (2001) & 154 & 31.2 & 59 \\
\hline
\end{tabular}

Inconsistency (homogeneity of studies); whether the studies present direct evidence; accuracy of the results presented in included studies; and if the systematic review has a publication bias, not including all the published studies about the research problem. Using these criteria, the level of evidence was classified, among the four levels presented by the GRADE system: high quality, moderate quality, low quality and very low quality. In high quality evidences, it is very unlikely that additional research change the prevalence estimate presented by the systematic review; When the study presents very low quality evidence, its prevalence estimate is very uncertain $^{29}$, thus new studies are necessary.

\section{RESULTS}

The initial search identified 1193 studies, of which 221 were duplicates, thus 972 remained. However, 950 were excluded based on the title and abstract, so that only 22 remained for detailed analysis, six of which were excluded after screening for the eligibility criteria. Manual searches were carried out in the references of the 16 studies, and a further 12 studies were included. Thus, 29 studies were reviewed. Figure 1 shows the flowchart of the study selection, Table 3 summarizes the characteristics of the studies and Table 4 explains the methodological quality of the studies.

In order to summarize the evidence from the 27 studies, with regard to postural deviations in the spine, we can list, in ascending order of involvements: lumbar hyperlordosis (found in 14 studies, prevalence between $19 \%$ and $78.1 \%$ ); Thoracic hyperkyphosis (found in 13 studies, prevalence between $9.7 \%$ and $49 \%$ ) and scoliosis (in four studies, prevalence between 5.2\% and $28 \%$ ). In addition, the contrasting sample sizes between the studies, from 47 to 1340 students, stand out. The number of studies carried out in the different geographic regions of Brazil, conducted mainly in the South $(\mathrm{n}=$ $14)$, followed by the Southeast $(n=7)$, and in a smaller number in the Northeast $(\mathrm{n}=4)$, also stand out, which is possibly related to regional economic constraints and resources.

Regarding the strength of evidence of this systematic review, based on the main criteria established by GRADE $^{29}, 14$ studies are in the high category of methodological quality, presenting an excellent agreement of punctuation between the reviewers (ICC = $0.833] 0.675 ; 0.918$ [p $<0.001)$, which implies a low risk of bias. However, with regard to inconsistency, high values were found, which reiterate the heterogeneity of the studies, making the quantitative informa- 
Figure 1: Flowchart of the search and selection of studies according to PRISMA.

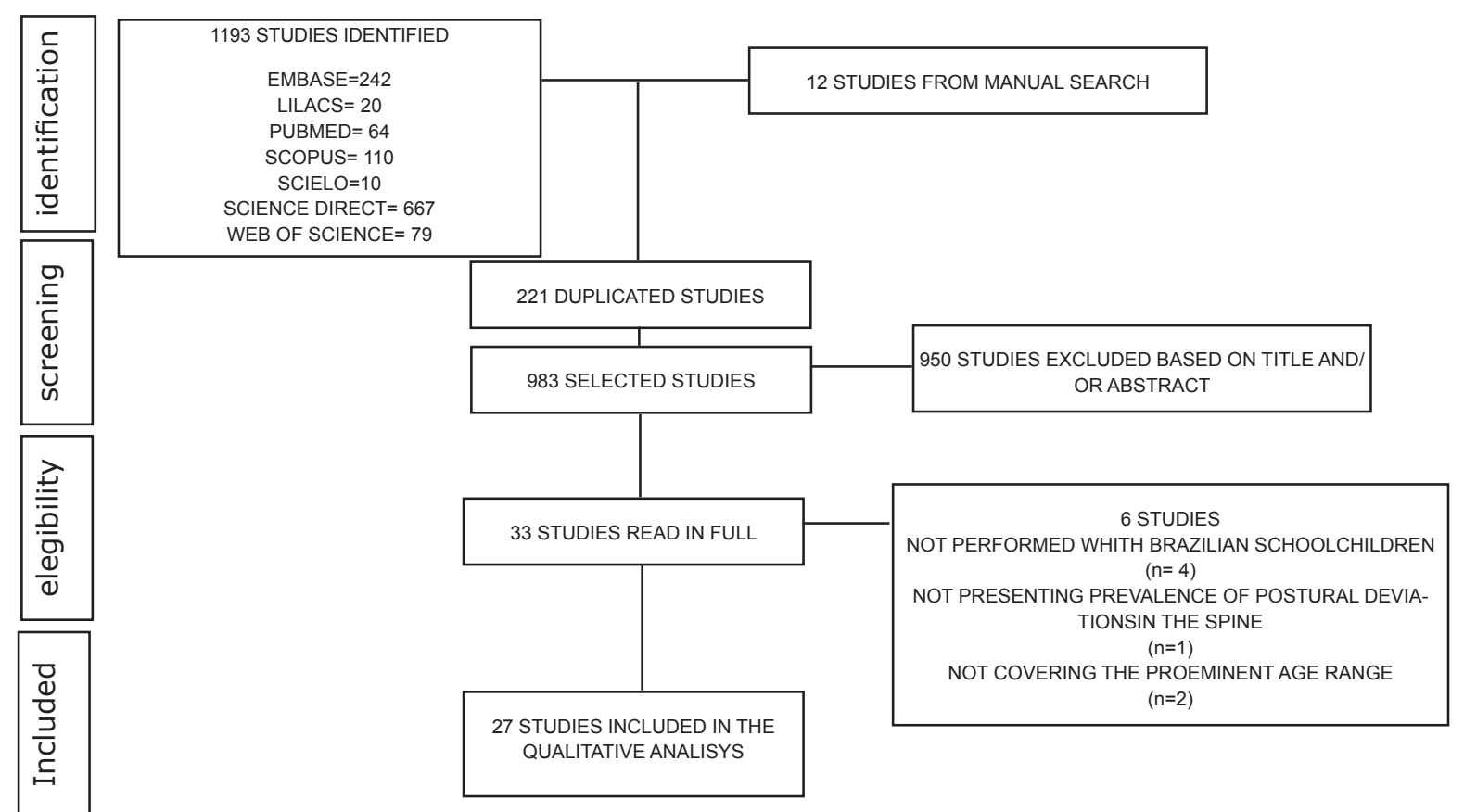

Table 3: Characteristics of the studies (in alphabetical order)

\begin{tabular}{|c|c|c|c|c|}
\hline Article & Location & Participants & Methods & Positive events (n) \\
\hline Baroni et al. (2015)36 & Santa Cruz, RN & $\begin{array}{l}n=212 \text { (from } 7 \text { to } 17 \text { years) } \\
58.5 \% \text { female; } 41.5 \% \text { male }\end{array}$ & Visual inspection & Possible scoliosis $=123$ \\
\hline Bastião et al. (2014)37 & São Paulo State & $\begin{array}{l}n=420 \text { (from } 1 \text { st to } 8 \text { th grade elementa- } \\
\text { ry school) } 60 \% \text { female; } 40 \% \text { male }\end{array}$ & Photogrammetry & $\begin{aligned} \text { Cervical hyperlordosis } & =87, \text { Thoracic hyperkyphosis }=170, \text { Lumbar } \\
& \text { hyperlordosis }=183\end{aligned}$ \\
\hline Bertolini, Gomes (1997)38 & Maringá, PR & $\begin{array}{l}n=200 \text { (from } 11 \text { to } 14 \text { years) } \\
59.5 \% \text { female; } 40.5 \% \text { male }\end{array}$ & Visual inspection & $\begin{aligned} \text { Cervical hyperlordosis } & =36, \text { Thoracic hyperkyphosis }=38, \text { Possible } \\
\text { scoliosis } & =29, \text { Lumbar hyperlordosis }=53\end{aligned}$ \\
\hline $\begin{array}{l}\text { Brianezi, Cajazeiro, Maifri- } \\
\text { no (2011)39 }\end{array}$ & Hortolândia, SP & $\begin{array}{l}n=201 \text { (from } 7 \text { to } 10 \text { years) } \\
52.2 \% \text { female; } 47.8 \% \text { male }\end{array}$ & Visual inspection & $\begin{array}{l}\text { Lumbar hyperlordosis }=81, \text { Thoracic hyperkyphosis }=88 \\
\text { Possible scoliosis }=102, \text { Lumbar hyperlordosis }=99\end{array}$ \\
\hline Bueno, Rech (2013)40 & Caxias do Sul, RS & $\begin{array}{l}n=864 \text { (from } 8 \text { to } 15 \text { years) } \\
49 \% \text { female; } 51 \% \text { male }\end{array}$ & Visual inspection & $\begin{array}{c}\text { Thoracic rectification }=143, \text { Thoracic hyperkyphosis }=30 \\
\text { Possible scoliosis }=287, \text { Lumbar hyperlordosis }=241 \\
\text { Lumbar rectification }=31, \text { Curve inversion }=2\end{array}$ \\
\hline $\begin{array}{l}\text { Contri, Petruchelli, } \\
\text { Perea (2009)41 }\end{array}$ & Porto Ferreira, SP & $\begin{array}{l}n=465 \text { (from } 7 \text { to } 12 \text { years) } 56 \% \\
\quad \text { female; } 44 \% \text { male }\end{array}$ & $\begin{array}{l}\text { Evaluation Form/ } \\
\quad \text { Visual }\end{array}$ & $\begin{array}{c}\text { Thoracic hyperkyphosis }=117, \text { Possible scoliosis }=64 \\
\text { Lumbar hyperlordosis }=144\end{array}$ \\
\hline $\begin{array}{l}\text { Correa, Pereira, Silva } \\
\text { (2005)42 }\end{array}$ & Barra Mansa, RJ & 72 (from 8 to 15 years) & Visual Inspection & $\begin{array}{c}\text { Thoracic hyperkyphosis }=20, \text { Possible scoliosis }=38 \\
\text { Lumbar hyperlordosis }=34\end{array}$ \\
\hline Detsch, Candotti (2001)43 & Novo Hamburgo, RS & $\begin{array}{c}n=154 \text { (from } 6 \text { to } 17 \text { years) } \\
\quad 100 \% \text { female }\end{array}$ & Visual Inspection & $\begin{array}{c}\text { Cervical anteriorization }=102, \text { Thoracic hyperkyphosis }=16, \\
\text { Lumbar hyperlordosis }=48\end{array}$ \\
\hline Detsch et al. (2007)44 & São Leopoldo, RS & $\begin{array}{c}n=495 \text { (from to } 14 \text { to } 18 \text { years) } \\
100 \% \text { female }\end{array}$ & Visual Inspection & Possible scoliosis $=327$ \\
\hline Dönert, Tomasi (2008)45 & Pelotas, RS & $\begin{array}{l}n=314 \text { (from } 9 \text { to } 16 \text { years) } 45.5 \% \\
\text { female; } 54.5 \% \text { male }\end{array}$ & Visual Inspection & Scoliosis $=28$ \\
\hline $\begin{array}{l}\text { Fornazari, Pereira } \\
\qquad(2008) 46\end{array}$ & Ribeirão Preto, SP & $n=49747 \%$ female $; 53 \%$ male & X-ray & Possible scoliosis $=108$ \\
\hline $\begin{array}{l}\text { Graup, Santos, Moro } \\
\text { (2010)47 }\end{array}$ & Florianópolis, SC & $\begin{array}{l}n=288 \text { (from } 15 \text { to } 18 \text { years) } 46 \% \\
\text { female; } 54 \% \text { male }\end{array}$ & Visual Inspection & Lumbar hyperlordosis $=14$, Lumbar rectification $=141$ \\
\hline Lemos et al. (2005)48 & General Câmara, RS & $\begin{array}{l}131 \text { (from } 10 \text { to } 13 \text { years) } \\
66.4 \% \text { female; } 36.6 \% \text { male }\end{array}$ & Photogrammetry & $\begin{array}{c}\text { Thoracic hyperkyphosis }=26, \text { Lumbar hyperlordosis }=85 \\
\text { Lumbar rectification }=3\end{array}$ \\
\hline $\begin{array}{l}\text { Lemos, Santos, Gaya } \\
\text { (2012)49 }\end{array}$ & Porto Alegre, RS & $\begin{array}{l}467 \text { (from } 10 \text { to } 16 \text { years) } 44.3 \% \\
\text { female; } 55.7 \% \text { male }\end{array}$ & Visual Inspection & $\begin{array}{c}\text { Cervical rectification }=56, \text { Cervical hyperlordosis }=114 \\
\text { Thoracic hyperkyphosis }=179\end{array}$ \\
\hline Martelli, Traebert (2006)50 & Tangará, SC & $\begin{array}{l}344 \text { (from } 10 \text { to } 16 \text { years) } \\
52.9 \% \text { female; } 47.1 \% \text { male }\end{array}$ & Visual Inspection & $\begin{array}{c}\text { Lumbar hyperlordosis }=365, \text { Thoracic hyperkyphosis }=38 \\
\text { Possible scoliosis }=30, \text { Lumbar hyperlordosis }=70\end{array}$ \\
\hline Nery et al. (2010)51 & Carlos Barbosa, RS & $\begin{array}{l}1340 \text { (from } 5 \text { th to } 8 \text { th grade elementary } \\
\text { school) } 49 \% \text { female; } 51 \% \text { male }\end{array}$ & Visual Inspection & Possibles coliosis $=19$ \\
\hline Noll et al. (2012)52 & Teutônia, RS & $\begin{array}{c}65 \text { (from } 11 \text { to } 16 \text { years) } 43 \% \text { female; } \\
57 \% \text { male }\end{array}$ & Visual Inspection & $\begin{array}{c}\text { Cervical anteriorization }=24 \text { Cervical retroversion }=18 \\
\text { Thoracic hyperkyphosis }=26 \text { Thoracic rectification= } 17 \\
\text { Possible scoliosis }=41 \text { Lumbar hyperlordosis }=30 \\
\text { Lumbar rectification }=2\end{array}$ \\
\hline
\end{tabular}




\begin{tabular}{|c|c|c|c|c|}
\hline Penha et al. (2005)53 & São Paulo, SP & $\begin{array}{l}132 \text { (from } 7 \text { to } 10 \text { years) } \\
100 \% \text { female }\end{array}$ & Photogrammetry & $\begin{array}{l}\text { Possible scoliosis }=41, \text { Lumbar hyperlordosis }=30 \\
\text { Lumbar rectification }=2 \text {, Thoracic hyperkyphosis }=45\end{array}$ \\
\hline Pereira et al. (2005)54 & Jequibé, BA & $\begin{array}{c}143 \text { (from } 10 \text { to } 15 \text { years) } 72.1 \% \text { female; } \\
27.9 \% \text { male }\end{array}$ & Visual Inspection & Possible scoliosis $=60$ \\
\hline Pinho, Duarte (1995)55 & Florianópolis, SC & $\begin{array}{l}229 \text { (from } 7 \text { to } 10 \text { years) } \\
48.5 \% \text { female; } 51.5 \% \text { male }\end{array}$ & Visual Inspection & $\begin{array}{c}\text { Thoracic hyperkyphosis }=59, \text { Possible scoliosis }=71 \\
\text { Lumbar hyperlordosis }=115\end{array}$ \\
\hline Rego, Scartoni (2008)56 & Teresina, PI & $4734 \%$ female; $66 \%$ male & Visual Inspection & Possible scoliosis $=24$ \\
\hline $\begin{array}{l}\text { Rocha, Tamatsu, Vilela } \\
\qquad(2012) 57\end{array}$ & Quixadá, CE & $\begin{array}{c}228 \text { (12 years) } 64.5 \% \text { female; } 35.5 \% \\
\text { male }\end{array}$ & Visual Inspection & Possible scoliosis $=110$ \\
\hline Rodrigues et al. (1985)58 & Rio Grande, RS & $\begin{array}{c}135 \text { (from } 6 \text { to } 14 \text { years) } 54.9 \% \text { female; } \\
45.1 \% \text { male }\end{array}$ & X-ray & Scoliosis $=7$ \\
\hline $\begin{array}{l}\text { Santo, Guimarães, } \\
\text { Galera (2011)59 }\end{array}$ & Cuiabá, MT & $\begin{array}{l}210 \text { ( } 3 \text { rd and } 4 \text { th grades) } \\
53.8 \% \text { female; } 46.2 \% \text { male }\end{array}$ & X-ray & $\begin{array}{c}\text { Scoliosis }=38 \text {, Cervical protusion }=29, \text { Thoracic hyperkyphosis }= \\
24, \text { Possible scoliosis }=39, \text { Lumbar hyperlordosis }=65\end{array}$ \\
\hline Santos et al. (2009)60 & Jaguariúna, SP & $\begin{array}{l}247 \text { (from } 6 \text { to } 13 \text { years) } \\
47 \% \text { female; } 53 \% \text { male }\end{array}$ & X-ray & $\begin{array}{c}\text { Cervical protusion }=29, \text { Thoracic hyperkyphosis }=24 \\
\text { Possible scoliosis }=39, \text { Lumbar hyperlordosis }=65\end{array}$ \\
\hline Sedrez et al. (2015)61 & Porto Alegre, RS & $\begin{array}{c}59 \text { (from } 7 \text { to } 18 \text { years) } \\
55.9 \% \text { female; } 44.1 \% \text { male }\end{array}$ & X-ray & $\begin{array}{c}\text { Thoracic hyperkyphosis }=30 \\
\text { Scoliosis }=29, \text { Lumbar hyperlordosis }=19\end{array}$ \\
\hline Souza et al. (2013)62 & Goiânia, GO & 418 (from 10 to 14 years) & X-ray & Scoliosis $=18$ \\
\hline
\end{tabular}

Table 4: Results of methodological quality assessment and studies bias risk

Methodological quality and risk of bias

Total Studies $1^{\text {st }}$ author (year) (Prevalence Critical Appraisal Instrument)

\begin{tabular}{|c|c|c|c|c|c|c|c|c|c|c|c|}
\hline $1^{\text {st }}$ author (year) & 1 & 2 & 3 & 4 & 5 & 6 & 7 & 8 & 9 & 10 & n of $\checkmark$ \\
\hline Baroniet al. (2015)36 & $\checkmark$ & $\checkmark$ & $\checkmark$ & $\checkmark$ & $\checkmark$ & $\checkmark$ & $?$ & $\checkmark$ & $\checkmark$ & $\checkmark$ & 9 \\
\hline Bastião et al.(2014)37 & $?$ & $\checkmark$ & $?$ & $X$ & $?$ & $\checkmark$ & $\checkmark$ & $\checkmark$ & $\checkmark$ & $\checkmark$ & 6 \\
\hline Bertolini, Gomes (1997)38 & $?$ & $?$ & $?$ & $X$ & $?$ & $\checkmark$ & $?$ & $?$ & $\mathrm{X}$ & $\mathrm{X}$ & 1 \\
\hline Brianezi, Cajazeiro and Maifrino (2011)39 & $?$ & $?$ & $?$ & $X$ & $?$ & $\checkmark$ & $?$ & $?$ & $x$ & $X$ & 1 \\
\hline Bueno, Rech (2013)40 & $\checkmark$ & $\checkmark$ & $\checkmark$ & $\checkmark$ & $\checkmark$ & $\checkmark$ & $\checkmark$ & $\checkmark$ & $\checkmark$ & $\checkmark$ & 10 \\
\hline Contri, Petrucelli, Perea (2009)41 & $?$ & $\checkmark$ & $?$ & $X$ & $\checkmark$ & $\checkmark$ & $?$ & $\checkmark$ & $X$ & $X$ & 4 \\
\hline Correa et al. (2005)42 & $?$ & $?$ & $?$ & $X$ & $\checkmark$ & $\checkmark$ & $?$ & $?$ & $X$ & $X$ & 2 \\
\hline DetschandCandotti (2001)43 & $?$ & $x$ & $?$ & $\checkmark$ & $?$ & $\checkmark$ & $\checkmark$ & $\checkmark$ & $\checkmark$ & $\checkmark$ & 6 \\
\hline Detschet al. (2007)44 & $\checkmark$ & $\checkmark$ & $\checkmark$ & $\checkmark$ & $\checkmark$ & $\checkmark$ & $\checkmark$ & $\checkmark$ & $\checkmark$ & $\checkmark$ & 10 \\
\hline Döhnert, Tomasi (2008)45 & $\checkmark$ & $\checkmark$ & $\checkmark$ & $\checkmark$ & $\checkmark$ & $\checkmark$ & $\checkmark$ & $\checkmark$ & $\checkmark$ & $\checkmark$ & 10 \\
\hline Fornazari, Pereira (2008)46 & $?$ & $\checkmark$ & $?$ & $\checkmark$ & $X$ & $\checkmark$ & $\checkmark$ & $\checkmark$ & $X$ & $X$ & 5 \\
\hline Graup, Santos, Moro (2010)47 & $\checkmark$ & $\checkmark$ & $\checkmark$ & $\checkmark$ & $?$ & $\checkmark$ & $\checkmark$ & $\checkmark$ & $\checkmark$ & $\checkmark$ & 8 \\
\hline Lemos et al. (2005)48 & $?$ & $?$ & $?$ & $\checkmark$ & $?$ & $\checkmark$ & $\checkmark$ & $\checkmark$ & $x$ & $X$ & 4 \\
\hline Lemos, Santos e Gaya (2012)49 & $?$ & $x$ & $?$ & $\checkmark$ & $?$ & $\checkmark$ & $\checkmark$ & $\checkmark$ & $\checkmark$ & $\checkmark$ & 6 \\
\hline Martelli, Traebert (2006)50 & $\checkmark$ & $\checkmark$ & $\checkmark$ & $\checkmark$ & $\checkmark$ & $\checkmark$ & $\checkmark$ & $\checkmark$ & $\checkmark$ & $\checkmark$ & 10 \\
\hline Nery et al. (2010)51 & $\checkmark$ & $\checkmark$ & $\checkmark$ & $\checkmark$ & $\checkmark$ & $\checkmark$ & $\checkmark$ & $\checkmark$ & $\checkmark$ & $\checkmark$ & 10 \\
\hline Noll et al. (2012)52 & $\checkmark$ & $?$ & $\checkmark$ & $\checkmark$ & $\checkmark$ & $\checkmark$ & $\checkmark$ & $\checkmark$ & $x$ & $\checkmark$ & 8 \\
\hline Penha et al. (2005)53 & $?$ & $\checkmark$ & $?$ & $\checkmark$ & $?$ & $\checkmark$ & $\checkmark$ & $\checkmark$ & $\checkmark$ & $\checkmark$ & 7 \\
\hline Pereira et al. (2005)54 & $\checkmark$ & $\checkmark$ & $?$ & $\checkmark$ & $\checkmark$ & $\checkmark$ & $\checkmark$ & $\checkmark$ & $\checkmark$ & $\checkmark$ & 9 \\
\hline Pinho, Duarte (1995)55 & $?$ & $?$ & $?$ & $\checkmark$ & $?$ & $\checkmark$ & $?$ & $\checkmark$ & $\checkmark$ & $\checkmark$ & 5 \\
\hline Rego, Scartoni (2008)56 & $?$ & $?$ & $?$ & $\checkmark$ & $?$ & $\checkmark$ & $?$ & $?$ & $x$ & $X$ & 3 \\
\hline Rocha, Tatmatsu, Vilela (2012)57 & $?$ & $\checkmark$ & $?$ & $\checkmark$ & $?$ & $\checkmark$ & $?$ & $?$ & $\checkmark$ & $\checkmark$ & 7 \\
\hline Rodrigues et al. (1985)58 & $?$ & $?$ & $?$ & $\checkmark$ & $\checkmark$ & $\checkmark$ & $\checkmark$ & $\checkmark$ & $\checkmark$ & $\checkmark$ & 5 \\
\hline Santo, Guimarães and Galera (2011)59 & $\checkmark$ & $\checkmark$ & $?$ & $?$ & $\checkmark$ & $\checkmark$ & $\checkmark$ & $\checkmark$ & $\checkmark$ & $\checkmark$ & 9 \\
\hline Santos et al. (2009)63 & $\checkmark$ & $\checkmark$ & $\checkmark$ & $\checkmark$ & $?$ & $\checkmark$ & $\checkmark$ & $\checkmark$ & $\mathrm{X}$ & $\checkmark$ & 8 \\
\hline Sedrezet al. (2014)64 & $\checkmark$ & $\checkmark$ & $\checkmark$ & $X$ & $\checkmark$ & $\checkmark$ & $\checkmark$ & $\checkmark$ & $\checkmark$ & $\checkmark$ & 9 \\
\hline Souza et al. (2013)62 & $X$ & $\checkmark$ & $X$ & $\checkmark$ & $\checkmark$ & $\checkmark$ & $\checkmark$ & $\checkmark$ & $x$ & $X$ & 6 \\
\hline
\end{tabular}

Responses to criteria: $\checkmark=$ Yes; $X=$ No, ?= Unclear

1. Was the sample representative of the target population?

2. Were the participants adequately recruited?

3. Was the sample size adequate?

4. Have the individuals and the recruitment environment been described in detail?

5. Was the data analysis done with sufficient coverage of the identified sample?

6. Were standard objective criteria used to measure the condition?

7. Was the condition measured reliably?

8. Was the statistical analysis appropriate?

9. Have all major confounding factors/subgroups/differences been identified and considered?

10. Were subpopulations identified with objective criteria? 
tion from analysis to meta-analysis inaccurate, a fact that is added to the high confidence intervals obtained in the calculations of prevalence by subgroup. Given the above, it is possible that future studies are likely to have a significant impact on the confidence in estimating the prevalence of postural deviations in the spine of schoolchildren, which makes this review with low strength of evidence.

\section{DISCUSSION}

The meta-analysis aimed to identify the prevalence of postural deviations in the spine of schoolchildren and adolescents in Brazil. Although the meta-analysis has a sample of individuals of over a thousand students in the analysis of each type of postural change, it was not possible to establish a consensus about the prevalence of anteroposterior and latero-lateral postural deviations in the spine of Brazilian schoolchildren. This result can be due the great heterogeneity of the studies, since they differ significantly regarding the methods used for evaluation of the posture and the sample space. Therefore, the prevalence of postural deviations were discrepant, reaching, thus, heterogeneity indexes above $90 \%$.

Among the ways of assessing spinal posture, visual inspection depends exclusively on the experience of the professional performing the assessment, besides not allowing to quantify objectively the changes, being an evaluation associated with major errors and disagreements $^{30,31}$. Likewise, the postural evaluation by photogrammetry, although providing quantitative evidence on the curvatures of the spine ${ }^{32}$, is also subject to recurrence of errors, either due to the inherent difficulty of palpation or by the different mathematical procedures that the software have ${ }^{33}$. In fact, the results of the studies that used photogrammetry were also discrepant with each other. Nevertheless, both methods, visual inspection and photogrammetry, were the most used by the studies included in this systematic review, factors that may contribute to the impossibility of reaching consensus on the prevalence of postural deviations in the Brazilian schoolchildren population.

Another factor that may have contributed to the variability of the results between the studies is a wide range of reference values for the classification of spinal curvatures. For example, for Bernhardt \& Bridwell ${ }^{34}$, Cobb angle values for a normal lumbar spine curvature ranged from $14^{\circ}$ to $69^{\circ}$, while for Propst-Proctor and Bleck ${ }^{35}$ they ranged from $22^{\circ}$ to $54^{\circ}$. In this sense, depending on the reference values used in the studies, these different spectra may have generated large differences in the posture classifications of the spine.

Despite the biases found in the methodologies of the studies included in this review, when the studies were submitted to the methodological quality and bias risk assessment through the Prevalence Critical Appraisal Instrument $^{24}, 14$ studies were classified with high quality. According to GRADE ${ }^{29}$, this result indicates a low risk of bias in the systematic review. Nevertheless, the meta-analysis indicates an inconsistency, due to the high heterogeneity among the studies. In this perspective, it is emphasized that there are studies of high methodological quality presenting the panorama of the problem of postural deviations in Brazilian schoolchildren, however such panoramas cannot be extrapolated to the context of the country, as they show only the reality of the region in which each study was developed. An example of this question is the fact that there are students whose habit of sleeping in hammocks is so recurrent that this factor was evaluated in the study by Baroni et al. ${ }^{36}$, being considered a protective factor for the development of scoliosis. This life habit was evaluated only in the study developed in north of Brazil, and was not found in any other Brazilian study. Therefore, since different regions of Brazil present different behavioral and life habits due to the different regional cultural influences, we can expect different types of postural deviations and different prevalence among their populations.

Thus, it was not possible to reach a consensus regarding the prevalence of postural deviations in the spine of Brazilian schoolchildren. From this perspective, we see the need for future studies designed to eliminate the biases pointed out by this systematic review, so that the Brazilian reality regarding the posture of the spine of schoolchildren can be documented. We understand that from a global knowledge, health promotion and education actions can be developed and put into practice at federal level, a fact that is still not possible today and therefore requires strategies at regional levels.

\section{CONCLUSION}

Based on the results obtained from the systematic review of articles developed in Brazil, we conclude that there is a low strength of evidence to establish a consensus about the values of prevalence of postural deviations in the spine of schoolchildren. We suggest that future studies be more rigorous in the screening and establishment of methodologies, as well as using validated instruments for evaluation, and investigating the macro and micro-regional differences of the states and the country.

\section{REFERENCES}

1. Galvão CM, Sawada NO, Trevizan MA. Revisão sistemática: recurso que proporciona a incorporação das evidências na prática da enferma na enfermagem. Rev Latino-Am Enferm. 2004;12(3):549-56. DOI: http://dx.doi.org/10.1590/ S0104-11692004000300014

2. Skoffer B, Foldspang A. Physical activity and low-back pain in schoolchildren. Eur Spine J. 2008;17(3):373-9. DOI: http://dx.doi.org/10.1007/s00586-007-0583-8 
3. Cakmak A, Yücel B, Özyalçn SN, Bayraktar B, Ural HI, Duruöz MT, et al. The frequency and associated factors of low back pain among a younger population in Turkey. Spine (Phila Pa 1976). 2004;29(14):1567-72. DOI: http:// dx.doi.org/10.1097/01.BRS.0000131432.72531.96

4. Paananen MV, Taimela SP, Auvinen JP, Tammelin TH, Kantomaa MT, Ebeling HE, et al. Risk factors for persistence of multiple musculoskeletal pains in adolescence : A 2-year follow-up study. Eur J Pain. 2010;14(10):1026-32. http:// dx.doi.org/10.1016/j.ejpain.2010.03.011

5. Lis AM, Black KM, Korn H, Nordin M. Association between sitting and occupational LBP. Eur Spine J. 2007;16(2):28398. DOI: http://dx.doi.org/10.1007/s00586-006-0143-7

6. Oshiro VA, Ferreira PG, Costa RF. Alterações posturais em escolares: uma revisão da literatura. Rev Bras Ciênc Saúde. 2007;5(13):15-22. DOI: http://dx.doi.org/10.13037/rbcs.vol5n13.396

7. Micheli L, Fehlandt AJ. Overuse injuries to tendons and apophyses in children and adolescents. Clin Sports Med. 1992;11(4):713-26.

8. Braccialli LMP, Vilarta R. Aspectos a serem considerados na elaboração de programas de prevenção e orientação de problemas posturais. Rev Paul Educ Fís. 2000;14(1):16-28.

9. Ainhagne M, Santhiago V. Cadeira e mochila escolares no processo de desenvolvimento da má postura e possíveis deformidades em crianças de 8-11 anos. Colloq Vitae. 2009;1(1):01-7. DOI: http://dx.doi.org/10.5747/cv.2009.v01. n1.v001

10. Grimmer K, Dansie B, Milanese S, Pirunsan U, Trott P. Adolescent standing postural response to backpack loads: a randomised controlled experimental study. BMC Musculoskelet Disord. 2002;3:10. DOI: http://dx.doi. org/10.1186/1471-2474-3-10

11. Politano RC. Levantamento dos desvios posturais em adolescentes de 11 a 15 anos em escola estadual do município de Cacoal - RO. Dissertação (Mestrado) - Universidade de Brasília. Brasília: 2006.

12. Aguiar NH, Bertolini SMMG. Estudo da incidência de cifose postural em crianças na faixa etária de 7 a 9 anos da rede escolar. Arq Ciênc Saúde Unipar. 1997;1(1):71-4.

13. Balagué F, Troussier B, Salminen JJ. Non-specific low back pain in children and adolescents: risk factors. Eur Spine J. 1999;8(6):429-38. DOI: http://dx.doi.org/10.1007/s005860050201

14. Silva MC, Fassa AG, Valle NCJ. Dor lombar crônica em uma população adulta do Sul do Brasil: prevalência e fatores associados. Cad Saude Publica. 2004;20(2):377-85. DOI: http://dx.doi.org/10.1590/S0102-311X2004000200005

15. Fathi M, Rezaei R. Comparison of height anomalies in middle school and high school students. Teach Phy Edu. 2011;11(1):46-53.

16. Zakeri Y, Baraz S, Gheibizadeh M, Nejad DB, Latifi SM. Prevalence of musculoskeletal disorders in primary school students in Abadan-Iran in 2014. Int J Pediatr. 2016;4(1):1215-23. DOI: http://dx.doi.org/10.22038/ijp.2016.6265

17. Murata Y, Utsumi T, Hanaoka E, Takahashi K, Yamagata M, Moriya H. Changes in lumbar lordosis in young patients with low back pain during a 10-year period. J Orthop Sci. 2002;7(6):618-22. DOI: http://dx.doi.org/10.1007/ s007760200111

18. Sano A, Hirano T, Watanabe K, Endo N, Ito T, Tanabe N. Body mass index is associated with low back pain in childhood and adolescence: a birth cohort study with a 6-year follow-up in Niigata City, Japan. Eur Spine J. 2015; 24(3):474-81. DOI: http://dx.doi.org/10.1007/s00586-014-3685-0

19. Galvão TF, Pereira MG. Revisões sistemáticas da literatura: passos para sua elaboração. Epidemiol Serv Saúde. 2014;23(1):183-4. DOI: http://dx.doi.org/10.5123/S1679-49742014000100018

20. The Joanna Briggs Institute (JBI). Joanna Briggs Institute reviewers' manual 2014: the systematic review of prevalence and incidence data. Austrália: 2014; p.37.

21. Higgins J, Green S. Cochrane handbook for systematic reviews of interventions. [Cited 2016 Dec 15] Available from: http://www.mri.gov.lk/assets/Uploads/Research/Cochrane-Hand-booktext.pdf

22. Stroup DF, Berlin JA, Morton SC, Olkin I, Williamson GD, Rennie D, et al. Meta-analysis of observational studies in epidemiology: a proposal for reporting. JAMA. 2000;283(15):2008-12. DOI: http://dx.doi.org/10.1001/ jama.283.15.2008

23. Pereira MG, Galvão TF. Etapas de busca e seleção de artigos em revisões sistemáticas da literatura. Epidemiol Serv Saúde. 2014;23(2):369-71. DOI: http://dx.doi.org/10.5123/S1679-49742014000200019

24. Munn Z, Moola S, Riitano D, Lisy K. The development of a critical appraisal tool for use in systematic reviews addressing questions of prevalence. Int J Heal Policy Manag. 2014;3(3):123-8. DOI: http://dx.doi.org/10.15171/ ijhpm.2014.71

25. Fleiss JN, Levin B, Paik MC. Statistical methods for rates and proportions. 3rd Ed. New York: 2004.

26. Schoonjans F. Medcalc statistics for biomedical research: software manual. Mariakerke: Medcalc Statistical Software; 2016; p. 295.

27. Santos GR, Abbud EL, Abreu AJ. Determination of the size of samples : an introduction for new researches. Rev Científica Symposiun. 2007;5(1):59-65.

28. Guyatt G, Oxman AD, Akl EA, Kunz R, Vist G, Brozek J, et al. GRADE guidelines : 1. Introduction-GRADE evidence profiles and summary of findings tables. J Clin Epidemiol. 2011;64(4):383-94. DOI: http://dx.doi.org/10.1016/j. jclinepi.2010.04.026 
29. Ministério da Saúde. Secretaria de Ciência, Tecnologia e Insumos Estratégicos Departamento de Ciência e Tecnologia. Diretrizes metodológicas: Sistema GRADE - Manual de graduação da qualidade de evidência e força de recomendação para tomada de decisão em saúde. Brasília: MS; 2014; p. 72.

30. Furlanetto TS, Chaise FDO, Candotti CT, Loss JF. Fidedignidade de um protocolo de avaliação postural. Rev Educ Física. 2011;22(3):411-9. DOI: http://dx.doi.org/10.4025/reveducfis.v22i3.10124

31. Chaise FO, Candotti CT, Torre ML, Furlanetto TS, Pelinson PPT, Loss JF. Validation, repeatability and reproducibility of a noninvasive instrument for measuring thoracic and lumbar curvature of the spine in the sagittal plane. Rev Bras Fisioter. 2011;15(6):511-7. DOI: http://dx.doi.org/10.1590/S1413-35552011005000031

32. D'Osualdo F, Schierano S, Cisotti C. The evaluation of the spine through the surface. The role of surface measurements in the evaluation and treatment of spine diseases in young patients. Eur Medicophys. 2002;38(3):147-52.

33. Iunes D, Bevilaqua-Grossi D, Oliveira A, Castro F, Salgado H. Análise comparativa entre avaliação postural visual e por fotogrametria computadorizada. Rev Bras Fisioter. 2009;13(4):308-15. DOI: http://dx.doi.org/10.1590/S141335552009005000039

34. Bernhardt M, Bridwell KH. Segmental analysis of the sagittal plane alignment of the normal thoracic and lumbar spines and thoracolumbar junction. Spine (Phila Pa 1976). 1989;14(7):717-21. DOI: http://dx.doi.org/10.1097/00007632198907000-00012

35. Propst-Proctor SL, Bleck EE. Radiographic determination of lordosis and kyphosis in normal and scoliotic children. J Pediatr Orthop. 1983;3(3):344-6. DOI: http://dx.doi.org/10.1097/01241398-198307000-00013

36. Baroni MP, Sanchis GJ, de Assis SJ, dos Santos RG, Pereira SA, Sousa KG, et al. Factors associated with scoliosis in schoolchildren: a cross-sectional population-based study. J Epidemiol. 2015;25(3):212-20. DOI: http://dx.doi. org/10.2188/jea.JE20140061

37. Bastião MV, Carnaz L, Barbosa LF, Motta GC, Sato T de O. Posture and musculoskeletal pain in eutrophic, overweighed, and obese students. A cross-sectional study. Motriz: Rev Educ Fis. 2014;20(2):192-9. DOI: http://dx.doi. org/10.1590/S1980-65742014000200009

38. Bertolini SMMG, Gomes A. Estudo da incidência de cifose postural em adolescentes na faixa etária de 11 a 14 anos da rede escolar de Maringá. Rev Educ Física. 1997;8(1):105-10.

39. Brianezi L, Cajazeiro DC, Maifrino LBM. Prevalence of postural deviations in school of education and professional practice of physical education. J Morphol Sci. 2011;28(1):35-6.

40. Bueno RCS, Rech RR. Postural deviations of students in Southern Brazil. Rev Paul Pediatr. 2013;31(2):237-42. DOI: http://dx.doi.org/10.1590/S0103-05822013000200016

41. Contri DE, Petrucelli A, Perea DCBNM. Incidência de desvios posturais em escolares do 20 ao 50 ano do Ensino Fundamental. ConScientiae Saúde. 2009;8(2):219-24. DOI: http://dx.doi.org/10.5585/conssaude.v8i2.1637

42. Correa AL, Pereira JS, Silva MAG. Avaliação dos desvios posturais em escolares: estudo preliminar. Fisioter Bras. 2005;6(3):175-8.

43. Detsch C, Candotti CT. A incidência de desvios posturais em meninas de 6 a 17 anos da cidade de Novo Hamburgo. Movimento. 2001;7(15):43-56.

44. Detsch C, Luz AMH, Candotti CT, Oliveira DS, Lazaron F, Guimarães LK, et al. Prevalência de alterações posturais em escolares do ensino médio em uma cidade no Sul do Brasil. Rev Panam Salud Pública. 2007;21(4):231-8. DOI: http://dx.doi.org/10.1590/S1020-49892007000300006

45. Dohnert MB, Tomasi E. Validade da fotogrametria computadorizada na detecção de escoliose idiopática adolescente. Rev Bras Fisioter. 2008;12(4):290-7. DOI: http://dx.doi.org/10.1590/S1413-35552008000400007

46. Fornazari LP, Pereira VCG. Prevalência de postura escoliótica em escolares do ensino fundamental. Cad Esc Saúde Fisioter. 2008;1(1):1-13.

47. Graup S, Santos SG, Moro ARP. Estudo descritivo de alterações posturais sagitais da coluna lombar em escolares da rede federal de ensino de Florianópolis. Rev Bras Ortop. 2010;45(5):453-9. DOI: http://dx.doi.org/10.1590/S010236162010000500013

48. Lemos A, Machado D, Moreira R, Torres L, Garlipp D, Lorenzi T, et al. Atitude postural de escolares de 10 a 13 anos de idade. Rev Perfil. 2005;7:53-9.

49. Lemos AT, Santos FR, Gaya ACA. Hiperlordose lombar em crianças e adolescentes de uma escola privada no Sul do Brasil : ocorrência e fatores associados. Cad Saude Publica. 2012;28(4):781-8. DOI: http://dx.doi.org/10.1590/ S0102-311X2012000400017

50. Martelli RC, Traebert J. Estudo descritivo das alterações posturais de coluna vertebral em escolares de 10 a 16 anos de idade: Tangará-SC, 2004. Rev Bras Epidemiol. 2006;9(1):87-93. DOI: http://dx.doi.org/10.1590/S1415790X2006000100011

51. Nery LS, Halpern R, Nery PC, Nehme KP, Stein AT. Prevalence of scoliosis among school students in a town in southern Brazil. Sao Paulo Med J. 2010;128(2):69-73. DOI: http://dx.doi.org/10.1590/S1516-31802010000200005

52. Noll M, Rosa BN, Candotti CT, Furlamentto TS, Gontijo KNS, Sedrez JA. Alterações posturais em escolares do en- 
sino fundamental de uma escola de Teutônia/RS. Rev Bras Ciênc Mov. 2012;20(2):32-42.

53. Penha PJ, João SMA, Casarotto RA, Amino CJ, Penteado DC. Postural assessment of girls between 7 and 10 years of age. Clinics. 2005;60(1):9-16. DOI: http://dx.doi.org/10.1590/S1807-59322005000100004

54. Pereira LM, Barros PCC, Oliveira MND, Barbosa AR. Escoliose: triagem em escolares de 10 a 15 anos. Rev Saúde Com. 2005;1(2):134-43.

55. Pinho RA, Duarte MFS. Analise postural em escolares de Florianopolis - SC. Rev Bras Ativ Física Saúde. 1995;1(2):4958.

56. Rego ARON, Scartoni FR. Alterações posturais de alunos de $5^{\mathrm{a}}$ e $6^{\mathrm{a}}$ séries do ensino fundamental. Fit Perform J. 2008;7(1):10-15. DOI: http://dx.doi.org/10.3900/fpj.7.1.10.p

57. Rocha JCT, Tatmatsu DIB, Vilela DA. Associação entre uso de mochilas escolares e escoliose em adolescentes de escolas públicas e privadas. Motricidade. 2012;8(S2):803-9.

58. Rodrigues CAC, Teixeira MAM, Casartelli MRO. Escoliose: levantamento epidemiológico em alunos da escola estadual Lilia Neves. Vittalle. 1985;1:67-76.

59. Espírito Santo A, Guimarães LV, Galera MF. Prevalência de escoliose idiopática e variáveis associadas em escolares do ensino fundamental de escolas municipais de Cuiabá, MT, 2002. Rev Bras Epidemiol. 2011;14(2):347-56.

60. Santos CIS, Cunha ABN, Braga VP, Saad IAB, Ribeiro MAGO, Conti PBM, et al. Ocorrência de desvios posturais em escolares do ensino público fundamental de Jaguariúna, São Paulo. Rev Paul Pediatr. 2009;27(1):74-80. DOI: http://dx.doi.org/10.1590/S0103-05822009000100012

61. Sedrez JA, Rosa MIZ, Noll M, Medeiros FS, Candotti CT. Risk factors associated with structural postural changes in the spinal column of children and adolescents. Rev Paul Pediatr. 2015;33(1):72-81. DOI: http://dx.doi.org/10.1016/j. rpped.2014.11.012

62. Souza FI, Ferreira RB, Labres D, Elias R, Souza APM, Pereira RE. Epidemiologia da Escoliose Idiopática do Adolescente em alunos da rede pública de Goiânia-GO. Acta Ortop Bras. 2013;21(4):2012-4. DOI: http://dx.doi.org/10.1590/ S1413-78522013000400008

63. Santos MM, Silva MPC, Sanada LS, Alves CRJ. Análise postural fotogramétrica de crianças saudáveis de 7 a 10 anos: confiabilidade interexaminadores. Rev Bras Fisioter. 2009;13(4):350-5. DOI: http://dx.doi.org/10.1590/S141335552009005000047

64. Sedrez JA, Furlanetto TS, Noll M, Gontijo KNS, Rosa BN, Candotti CT. Relação entre alterações posturais e fatores associados em escolares do ensino fundamental. Rev Baiana Saúde Pública. 2014;38(2):279-96. DOI: http://dx.doi. org/10.5327/Z0100-0233-2014380200005

\section{Supplementary material}

Table 1: Results of the meta-analysis for prevalence of alterations in the cervical spine

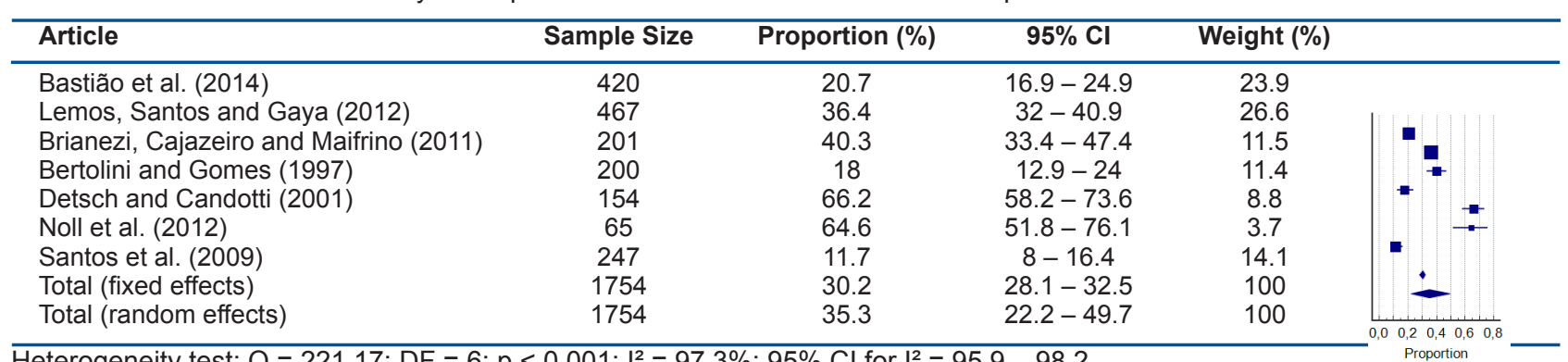

Heterogeneity test: $\mathrm{Q}=221.17 ; \mathrm{DF}=6 ; \mathrm{p}<0.001 ; \mathrm{I}^{2}=97.3 \% ; 95 \% \mathrm{Cl}$ for $\mathrm{I}^{2}=95.9-98.2$

Table 2: Results of the meta-analysis for prevalence of changes in the thoracic spine

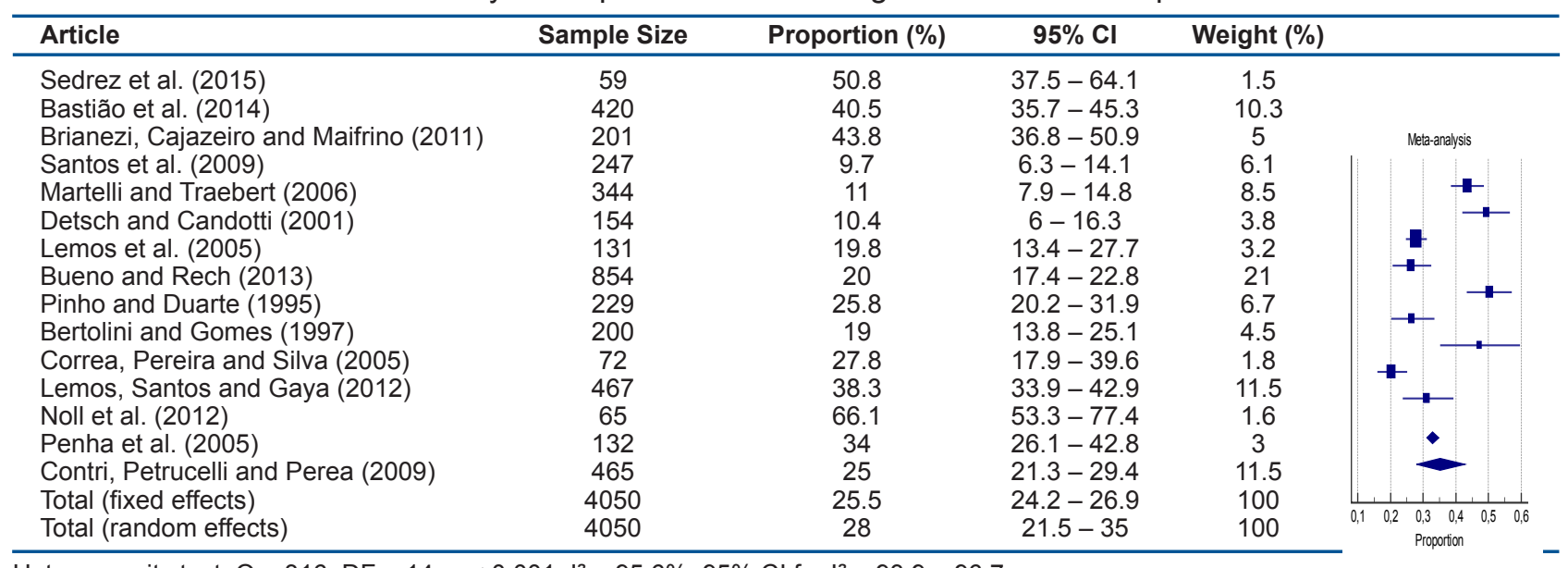

Heterogeneity test: $Q=316 ; D F=14 ; p<0.001 ; I^{2}=95.6 \% ; 95 \% C l$ for $I^{2}=93.9-96.7$ 
Table 3: Results of the meta-analysis for prevalence of lumbar spine alterations

\begin{tabular}{|c|c|c|c|c|c|}
\hline Article & Sample Size & Proportion (\%) & $95 \% \mathrm{Cl}$ & Weight (\%) & \\
\hline Bastião et al. (2014) & 420 & 43.5 & $38.8-48.5$ & 15.4 & \\
\hline Brianezi, Cajazeiro and Maifrino (2011) & 201 & 49.2 & $42.1-56.4$ & 7.4 & $\Rightarrow$ \\
\hline Bueno and Rech (2013) & 864 & 27.9 & $24.9-31$ & 31.6 & + \\
\hline Santos et al. (2009) & 247 & 26.3 & $20.9-32.3$ & 9 & $\Rightarrow$ \\
\hline Pinho and Duarte (1995) & 229 & 50.2 & $43.3-56.9$ & 8.4 & \\
\hline Bertolini and Gomes (1997) & 200 & 26.5 & $20.5-33.2$ & 7.3 & \\
\hline Correa, Pereira and Silva (2005) & 72 & 47.2 & $35.3-59.3$ & 2.7 & \\
\hline Martelli and Traebert (2006) & 344 & 20.3 & $16.2-25$ & 12.6 & - \\
\hline Detsch and Candotti (2001) & 154 & 31.2 & $23.9-39.1$ & 5.6 & - \\
\hline Total (fixed effects) & 2731 & 32.9 & $31.2-34.7$ & 100 & \\
\hline Total (random effects) & 2731 & 35.7 & $28.1-42.8$ & 100 & Proportion \\
\hline
\end{tabular}

Heterogeneity test: $Q=124.9 ; \mathrm{DF}=8 ; \mathrm{p}<0.001 ; \mathrm{I}^{2}=93.6 \% ; 95 \% \mathrm{Cl}$ for $\mathrm{I}^{2}=89.9-95.2$

Table 4: Results of the meta-analysis for prevalence of Scoliosis

\begin{tabular}{lcccc}
\hline Article & Sample Size & Proportion (\%) & $\mathbf{9 5 \% ~ C l}$ & Weight (\%) \\
\hline Sedrez et al. (2015) & 59 & 49.1 & $35.9-62.5$ & 3.6 \\
Santo, Guimarães and Galera (2011) & 210 & 18.1 & $13.1-23.9$ & 12.9 \\
Döhnert and Tomasi (2008) & 314 & 8.9 & $6-12.6$ & 19.3 \\
Souza et al. (2013) & 418 & 4.3 & $2.6-6.7$ & 25.5 \\
Rodrigues et al. (1985) & 135 & 5.2 & $2.1-10.4$ & 8.3 \\
Fornazari and Pereira (2008) & 497 & 8.8 & $6.5-11.7$ & 30.4 \\
Total (fixed effects) & 1633 & 9.3 & $7.9-10.8$ & 100 \\
Total (random effects) & 1633 & 12.9 & $6.7-20.8$ & 100 \\
\hline
\end{tabular}

Heterogeneity test: $\mathrm{Q}=86.12 ; \mathrm{DF}=5 ; \mathrm{p}<0.001 ; \mathrm{I}^{2}=94.2 \% ; 95 \% \mathrm{Cl}$ for $\mathrm{I}^{2}=89.9-96.6$

This article is distributed under the terms of the Creative Commons Attribution 4.0 International License (http://creativecommons.org/licenses/by/4.0/), which permits unrestricted use, distribution, and reproduction in any medium, provided you give appropriate credit to the original author(s) and the source, provide a link to the Creative Commons license, and indicate if changes were made. The Creative Commons Public Domain Dedication waiver (http://creativecommons.org/publicdomain/zero/1.0/) applies to the data made available in this article, unless otherwise stated.

\section{Resumo}

Introdução: A Era da informação e da tecnologia tem causado grande impacto na vida dos cidadãos. As invenções de máquinas, de automóveis, da televisão e do computador, induziram os indivíduos a adotarem a postura corporal "sentada" a fim de se adaptar as novas necessidades tecnológicas.

Objetivo: Estimar a prevalência de alterações posturais na coluna vertebral de escolares brasileiros.

Método: Foram realizadas buscas nas bases de dados EMBASE, LILACS, PubMed, SCOPUS, SciELO, Science Direct, e Web of Science, além de buscas manuais a fim de identificar estudos que avaliassem a prevalência de alterações posturais na coluna vertebral em escolares brasileiros. Dois revisores independentes realizaram a seleção dos estudos, avaliaram a qualidade metodológica e o risco de viés dos estudos selecionados e extraíram os dados. Foi realizada a análise de homogeneidade interestudos e a qualidade do nível de evidência foi avaliada utilizando o sistema GRADE.

Resultados: Foram incluídos 29 estudos, dos quais foram extraídas as frequências de eventos positivos para as alterações na coluna cervical, torácica, lombar, bem como a frequência de escoliose entre os escolares. Mesmo realizando a metanálise separada por subgrupos de acordo com a região vertebral avaliada, o nível de heterogeneidade ficou a cima dos $90 \%$, não sendo possível estipular a prevalência de alterações posturais na coluna vertebral em escolares brasileiros a partir da metanálise.

Conclusão: Existe baixa força de evidência para se estabelecer um consenso acerca dos valores de prevalência de desvios posturais na coluna vertebral de escolares brasileiros.

Palavras-chave: postura, coluna, criança, adolescente. 